\title{
Sürdürülebilir ve Akıllı Kentler: Marmara Depremi ${ }^{1}$
}

\section{Dilek Çetin²}

ORCID: 0000-0002-0854-8746

\author{
Yağmur Kara ${ }^{3}$ \\ ORCID: 0000-0001-5377-5561
}

\author{
Zeynep Ceren \\ Henriques Correia ${ }^{4}$ \\ ORCID: 0000-0002-1080-4905
}

\section{Öz}

Sürdürülebilir kalkınma dünyadaki tüm ülkelerin sürdürdüğ̈̈ ekonomik ve sosyal politikaların temelini oluşturmaktadır. 2018 yılında dünya nüfusunun \%55,3'ü kentlerde yaşamaktadır ve 2030 yılında da bu oranın \%75'i aşması beklenmektedir. Bu bağlamda kentsel büyümenin denetlenmesi ve yönlendirilmesi gerekmektedir. İleriye dönük bir kent politikasından yoksun büyüyen kentler afetler karşısında çaresiz kalmaktadırlar. Kentsel yaşam kalitesinin arttırılmasıyla birlikte kentin doğa ile uyumunun sağlanması gerekmektedir. Sürdürülebilir kentler, insanın doğa ile uyumunun să̆lanmasını ve afetlere karşı kentlerin hazır olmasın să̆larken akıll kentler ise bilgi iletişim teknolojilerini kullanarak afetler sonrasında kentlerin daha planlı bir şekilde toparlanmasına yardımcı olacaktır. Bu sayede de afetler karşısında şehirler çaresiz kalmayacaktır. Türkiye'de ulusal ya da sektörel afetle mücadele politikası izlemektense, bir niş olarak kent ortaya çıkmaktadır. Türkiye tarihinde afet kaynaklı en büyük kaybı yaşadığımız 1999 Marmara Depremi bu kavramlar dâhilinde incelenecektir. Türkiye'de sürdürülebilir ve akill kentler kapsamında kaderci, iyileştirici, reaktif bir devletten, kendine güvenen, koruyucu ve pro-aktif devlete dönüşümün sağlanması gerekmektedir. Kentlerin afetlere karşı hazırlıklı olabilmesi için hem sürdürülebilir hem de akıllı olması gerektiği aşikârdır.

Anahtar Kelimeler: Afet, Sürdürülebilir Kent, Akıllı Kent, Marmara Depremi, Türkiye

\footnotetext{
${ }^{1}$ Makalenin ilk hali, "Afetlerle Sürdürülebilir Kentler ve Türkiye Deneyimleri” adıyla EconAnadolu 2017-Anadolu Uluslararası İktisat Kongresi bildiriler kitabında özet bildiri olarak basılmıştir.

${ }^{2}$ Doç. Dr., Süleyman Demirel Üniversitesi, E-mail: dilekcetin@sdu.edu.tr

${ }^{3}$ Dr. Öğr. Üyesi, Muğla Sttkı Koçman Üniversitesi, E-mail: ykara@mu.edu.tr

${ }^{4}$ Dr., Kirıkkale Üniversitesi, E-mail: zeynepcerenakyuz@gmail.com

idealkent (c) Kent Araştırmaları Dergisi (Journal of Urban Studies)

http://idealkentdergisi.com

Geliş Tarihi Received Date: 10.05.2020 Kabul Tarihi Accepted Date: 22.12.2020
} 


\title{
The Sustainable and Smart Cities: Marmara Earthquake ${ }^{5}$
}

\author{
Dilek Çetin 6 \\ Yağmur Kara ${ }^{7}$ \\ Zeynep Ceren \\ Henriques Correia ${ }^{8}$ \\ ORCID: 0000-0002-0854-8746 \\ ORCID: 0000-0001-5377-5561 \\ ORCID: 0000-0002-1080-4905
}

\begin{abstract}
Sustainable development is the foundation of economic and social policies for all countries in world. In 2018,55.3\% of the world population lives in cities and this ratio is expected to exceed $75 \%$ in 2030. In this context, the growth of cities should be controlled and directed. The cities, without a forward looking city policy, are in desperate straits towards to disasters. The city should be harmonized with the nature meanwhile enhancing the city life quality. Sustainable cities ensure harmony between the men and the nature and prepare the city to disasters while smart cities help to recover cities by means of information communication technologies. Thus, the cities would not be vulnerable against the disasters. In Turkey, instead following a national or sectorial disaster struggle polices, cities emerge as a niche. 1999 Marmara earthquake, the highest loss from a disaster in the history of Turkey, analyzed according to these concepts. The government should transform from fatalistic, curative, reactive to self-confident, protective and pro-active in the framework of sustainable and smart cities in Turkey. It is clear that cities need to be sustainable and smart to be prepared for the disasters.
\end{abstract}

Keywords: Disaster, Sustainable City, Smart City, Marmara Earthquake, Turkey

\footnotetext{
${ }^{5}$ The first version of the article is published at book of abstract of EconAnadolu 2017-Anatolian International Economy Congress as "Sustainable Cities with Disasters and Turkish Experience". ${ }^{6}$ Assoc. Prof., Süleyman Demirel University, E-mail: dilekcetin@sdu.edu.tr

7 Assist. Prof., Muğla Sıtkı Koçman University, E-mail: ykara@mu.edu.tr

${ }^{8}$ Dr., Kirıkkale University, E-mail: zeynepcerenakyuz@gmail.com

idealkent (c) Kent Araştırmaları Dergisi (Journal of Urban Studies)

http://idealkentdergisi.com
}

Geliş Tarihi Received Date: 10.05.2020 Kabul Tarihi Accepted Date: 22.12.2020 


\section{Giriş}

Sürdürülebilir kalkınmanın sağlanması tüm ülkelerin sürdürdüğü ekonomik, sosyal ve çevre politikaların temelini oluşturmaktadır. "Sürdürülebilir Kentler" de sürdürülebilir kalkınmanın temel taşlarından biridir. 2010 yılında tüm dünya nüfusunun yüzde 50 'den fazlası kentlerde yaşamaktadır ve 2030 yılında bu oranın yüzde 75'i aşması beklenmektedir. Bu bağlamda kentsel büyümenin denetlenmesi ve yönlendirilmesi gerekmektedir. İleriye dönük bir kent politikasından yoksun büyüyen kentler özellikle afetler karşısında çaresiz kalmaktadırlar. Ekonomik, sosyal ve çevresel anlamda kentsel yaşamın iyileştirilmesiyle birlikte kentin doğa ile uyumu sağlanacak ve bu sayede de afetler karş1sında çaresiz kalınmayacaktır. Türkiye'de de ulusal ya da sektörel afetle mücadele politikası izlemektense, bir niş olarak ortaya çıkn kenti merkeze koyan politikalar izlemenin düşünülmesi ve yollarının aranması anlam kazanmaktadır. Bu kapsamda kaderci, iyileştirici, reaktif bir devletten, kendine güvenen, koruyucu ve pro-aktif devlete dönüşümün sağlanması gerekmektedir.

Doğal afet sonrasında acil müdahale durumunda Bilgi İletişim Teknolojilerinin (BİT) kullanımın gerekliliği de "Akıllı Kentlerin" önemini ortaya koymaktadır. Sürdürülebilir ve Akıllı Kentlerin oluşturulabilmesi için yerel yönetimlere önemli görevler düşmektedir. Çalışmanın birinci bölümünde "Sürdürülebilir Kent" kavramı, ikinci bölümde ise "Akıllı Kent" kavramları açıklanmaya çalışllacaktır. Son olarak üçüncü bölümde Gölcük-Kocaeli Depremi bu kavramlar kapsamında ele alınacaktır.

\section{Sürdürülebilir Kent}

"Sürdürülebilir Kentler" kavramına geçmeden önce "Sürdürülebilirlik" kavramının açıklanması gerekmektedir. "Sürdürülebilirlik" kavramı ile "Sürdürülebilir Kent" kavramı arasında bağlantı kurulduktan sonra "Sürdürülebilir Kent" kavramı ve boyutları açıklanmaya çalışılacaktır.

\section{Dünyanın İhtiyaç Duyduğu Kavram “Sürdürülebilirlik”}

"Sürdürülebilirlik" kavramı dünyanın yaşanabilir bir yer olup olmadığı tartışmaları ile İkinci Dünya Savaşı sonrasında başlamıştır (Kidd, 1992). Normatif bir kavram olarak muğlaklığı hala tartısılmaktadır (Kates vd., 2005; Tanguay vd., 2010). Savaşın yıkıcı etkilerinin yanı sıra dünyanın karşı karşıya kaldığı küresel çevresel tahribatın yanında giderek artan yoksulluk ve sosyal eşitsizlik de, odak noktasına yalnızca ekonomik büyümeyi alan politikaların tartısılmasına sebep olmuştur. Kümülatif olarak artan ve küresel ölçekte dünya nüfusunun 
önemli bir kısmını etkileyen bu sorunlar "şimdi büyü sonra temizlersin" bakış açısının gölgesinde kalmıştır. Ancak Yirminci Yüzyılın ikinci yarısında ekonomik zenginliğin toplumsal refah anlamına gelmediğini gösteren İnsani Kalkınma Endeksi gibi ampirik çalışmalarla birlikte sürdürülebilirlik kavramı gün geçtikçe dikkat çekici bir kavram haline gelmiş; uluslararası kuruluşlar, araştırmacılar, politika yapıcılar ve paydaşların kavrama duydukları ilgi giderek artmiştır.

1968 yılında toplanan Roma Kulübü, sürdürülebilirlik kavramsal olarak henüz tanımlanmamış olsa da, fiziki büyümenin bir sınırı olduğunu vurguladığında, bu çıkıs büyük ses getirmiştir. Bu toplantyya kadar pek çok ülke kalkınma politikalarını hazırlarken doğal kaynakların sınırlı olduğunu ve ekosistemin bir taşıma kapasitesi olduğunu göz ardı etmiştir. Milli Gelir hesapları ise ekonomik gelişmişlik performansı karşılaştırmalarında kullanılan en önemli değişken olmuştur. Toplantının ardından Roma Kulübünün 1972 yılında yayınlamış olduğu "Büyümenin Sınırları" çalışması (Meadows vd., 1972) ile yalnızca ekonomik büyümeye odaklanmanın ekoloji üzerinde yarattı̆̆ baskı ve tahribat vurgulanmıştır. Ayrıca ekonomik yapı ile doğal çevrenin karşılıklı bağımlılığının göz ardı edilemeyeceği ifade edilmiştir. Söz konusu raporda doğanın bir taşıma kapasitesi olduğuna özellikle dikkat çekilmiştir. Taşıma kapasitesi bir ekosistemin devamlılı̆̆ının sağlanması için, o ekosistemin ulaşabileceği maksimum canlı sayısını ifade eder (Bell ve Morse, 2008). Büyük yankı bulan Büyümenin Sınırları çalışması, o yıllarda bir kıyamet senaryosu gibi algılanmıştır (Holden vd., 2008). Ancak raporun odak noktası böyle bir algı oluşturmaktan daha çok fiziki büyümenin bir sınırı olduğu ve bu sınıra çoktan gelindiği konusunda küresel bir farkındalık yaratmaktır. Bu amaçla sıfır büyüme ile devam ederken aynı zamanda gelecek nesillerin yaşam haklarının da göz önünde bulundurulduğu politikalar oluşturulması ve uygulanması gerekliliği vurgulanmıştır.

Büyümenin Sınırları çalışmasının yayınlanmış olduğu 1972 yılında Birleşmiş Milletler tarafından organize edilen Stockholm Konferans1 $1^{9}$ (İnsan Çevresi Konferansı) toplanmıştır. Konferans; her bireyin sağlıklı bir çevrede yaşama hakkı olduğunu vurgulaması ve küresel çevre sorunlarına dikkat çekmesinden ötürü büyük ilgi çekmiştir. Konferans gelişmiş ve gelişmekte olan ülkelerin temsilcilerinin "büyüme" üzerine karşlıklı tartışmalarının gölgesinde kalmışsa da, sonuç bildirgesi önemli çevresel kaygilar üzerine bir referans kaynak olmuştur (Handl, 2020).

\footnotetext{
${ }^{9}$ Konferansin orijinal ismi "Declaration of the United Nations Conference on the Human Environment"dir.
} 
Bu iki önemli rapordan sonra Dünya Koruma Birliği'nin 1980 yılında hazırladığı Dünya Koruma Strateji Raporunda sürdürülebilirlik kavramının temelleri atılmıştır. Raporun "varlığını sürdürebilen bir toplum için gelecek kuşakların beklentilerinin eksiltilmemesi" vurgusu (Brown, 1981) 80'li yıllara yön vermiştir. Literatüre bakıldığında sürdürülebilirliğin çok sayıda tanımı yapılmış olsa da, Birleşmiş Milletler Dünya Çevre ve Gelişme Komisyonu tarafından hazırlanan ve Brundtland Raporu olarak da bilinen rapordaki tanım genel kabul görmüştür. Buna göre sürdürülebilirlik "şimdiki neslin ihtiyaçları karşılanırken, gelecek nesillerin ihtiyaçlarını karşılama yeteneklerinin ellerinden alınmaması" olarak tanımlanmıştır (WCED, 1987).

Sürdürülebilirlik kavramının ilk çıkış noktasında çevresel kaygılar yer almıştır. Ancak zaman içinde sürdürülebilirlik; ekonomik, sosyal ve çevresel bileşenleri bir arada değerlendirmeyi gerektiren, çok daha geniş kapsamlı bir kavram halini almıştır. Buna göre sürdürülebilirlikten söz edebilmek için; ekonomik büyümenin yanı sıra yenilenebilir kaynakların kullanımı, biyolojik çeşitliliğin devamı, atmosferik denge ve ekosistemin korunması gibi çevresel; eğitim ve sağlıkta eşitlik, politik sorumluluk ve katılım gibi sosyal olmak üzere çok sayıda faktörün dengeli bir sentezi gereklidir.

Sürdürülebilirlik kavramına verilen önem ve duyulan ilgi yıllar içinde artmış ve pek çok platform da tartı̧ılır olmuştur. Amsterdam'da düzenlenen “Değişen Dünyadaki Zorluklar 2001" Dünya Kongresinde sürdürülebilirlik yeni bir akademik disiplin olarak kabul edilmiştir (Kates vd., 2001). Buna göre sürdürülebilirlik, küresel ve yerel bakış açılarını doğa bilimleri, sosyal bilimler, mühendislik ve tıp alanlarının bir bileşimi olarak gören disiplinler arası bir bilim (Clark ve Dickson, 2003) olarak tanımlanmıştır.

\section{Sürdürülebilirlik Vurgusundan Sürdürülebilir Kentlere}

Sürdürülebilirlik kavramı çevresel, ekonomik ve sosyal bileşenleri ile benimsendikçe yalnızca ulusal kalkınma stratejileri gibi makro ölçekte değil aynı zamanda mikro ölçekte de kullanılmaya başlanmıştır. Bölgesel sürdürülebilirlikten kentlere, firmalardan binalara kadar çok farklı ölçeklerde incelenmiştir. Ancak Dünya nüfusunun kent-kır dağılımında yaşanan radikal değişiklikler ve kentlerde artan nüfus baskısı, sürdürülebilirliği kent ölçeğinde incelemeyi zorunlu kılmaktadır. Kentler; nüfus, kaynaklar, bilgi, ekonomik güç ve fırsatların olduğu kadar, kirlilik, trafik karmaşası ve suç gibi negatif pek çok unsurun da birer yoğunlaşma noktalarıdır (Bugliarello, 2006). 


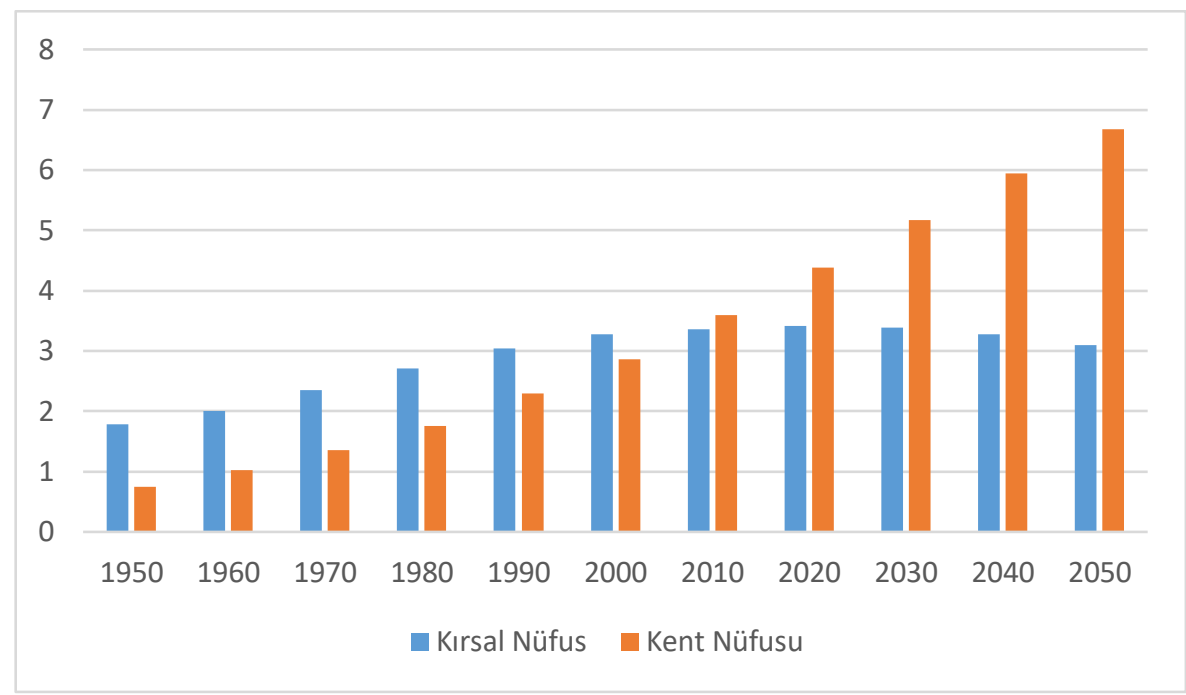

Şekil 1. Dünyada Kent ve Kır Nüfuslarının Yıllara Göre Değişimi (1.000.000)

(UN, 2018)

Dünya nüfusunun kent ve kırsal alandaki dağılımı 50'li yıllardan günümüze dramatik bir değişime uğramıştır. Birleşmiş Milletler Nüfus Biriminin (UN, 2018) yayınladığı nüfus istatistikleri kullanılarak hazırlanan Şekil 1 incelendiğinde 1950 yılından 2000'lere kadar kırsalda yaşayan nüfusun kentlerde yaşayan nüfustan her zaman fazla olduğu görülmektedir. Ancak burada dikkat çeken bir başka nokta aradaki makasın giderek daraldığıdır. 2008 yılı nüfus istatistikleri yayınlandığında ise dünya tarihinde ilk defa kentlerde yaşayan nüfusun kırsalda yaşayan nüfusu geçtiği görülmüsştür. 2020 yılında 4,4 milyar insan kentlerde yaşamaktayken, yapılan nüfus projeksiyonlarına göre $2050 \mathrm{yl}-$ lında bu sayı 6,7 milyara yükselecektir (UN, 2018). Dünyanın yaşadığı nüfus hareketliliğinin yanı sıra önümüzdeki 30 yıl içinde karşılaşacağı bu tablo sürdürülebilir kentleri daha da önemli hale getirecektir. 


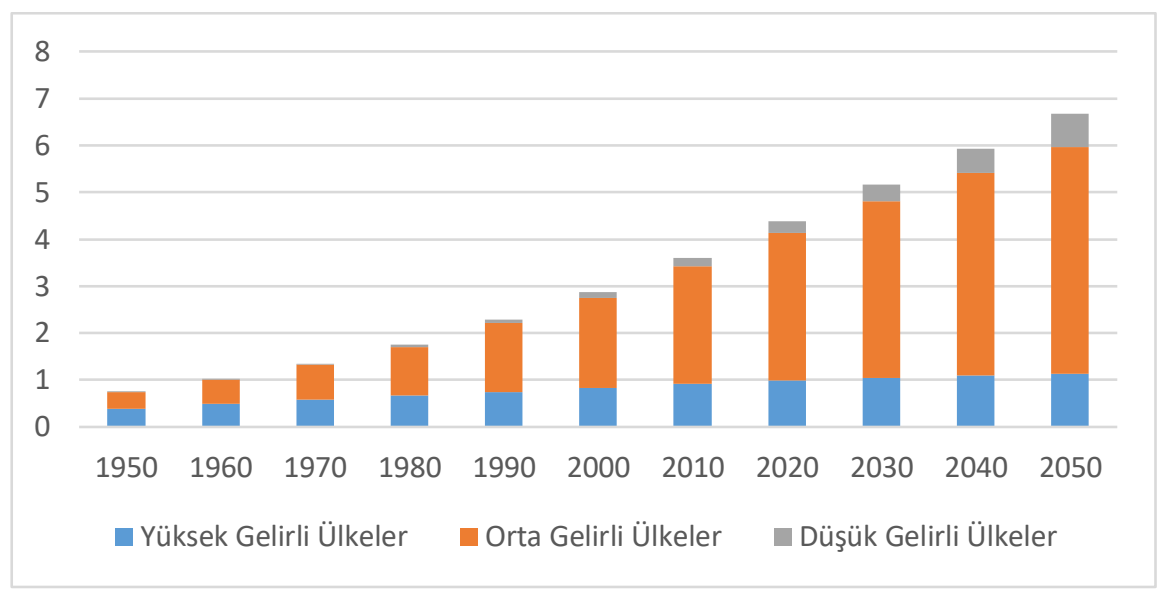

Şekil 2. Yıllara Göre Kentlerde Yaşayan Nüfusun Gelir Gruplarına Göre Dağılımı (1.000.000) (UN, 2018)

Şekil 2' de kentlerde yaşayan nüfusun yıllara göre ve gelir gruplarına göre dağılımı görülmektedir (UN, 2018). Düşük, orta ve yüksek gelir grubunda yer alan ülke gruplarında kent nüfusu son 70 yılda artış göstermiştir. Ancak özellikle dikkat çeken, kent nüfusunun düşük ve orta gelirli ülke gruplarındaki artış olmaktadır. 1950 yılına göre 2020 yılında orta gelir grubu ülkelerde kent nüfusu 9,1 kat, düşük gelir grubu ülkelerde ise 20,4 kat artmıştır. Yüksek gelir grubu ülkeler için bu artış 2,5 katı olacak şekilde gerçekleşmiştir.

Dünyada kent nüfusu artmaya devam ettikçe "ekolojik ayak izi" kavramı da giderek önem kazanmaya ve popüler hale gelmeye başlamıştır. Kavram insan ihtiyaçlarını, bu ihtiyaçları karşılayabilmek için dünya üzerinde ne kadar araziye ihtiyaç duyulduğuna dönüştüren bir kavramdır (Rees, 1992). Ekolojik ayak izini ölçmede kullanılan endeks, bireyin ya da toplumun herhangi bir faaliyet sonucu tükettiği kaynakları elde edebilmek ve ortaya çıan atığı ortadan kaldırmak için ihtiyaç duyulan, biyolojik olarak verimli toprak ve su alanlarını hesaplayan bir endekstir. (Wackernagel, 1994; Wackernagel ve Rees, 1996). Endeks kullanarak yapılan hesaplamalara göre; günümüzde insanlığın ihtiyaçlarını karşılamak için 1,6 adet dünyaya ihtiyaç duyulurken, bu oranın 2030'larda 2 dünyaya çıkması beklenmektedir (GFN, 2015).

Her bir bireyin ihtiyaçlarının karşılanmasında ekolojik ayak izi oluşurken, insanların toplu halde yaşadıkları kentler de kendi ayak izlerini oluştururlar. Bir vatandaşın ekolojik izini, Wackernagel ve Rees (1996) Amerika Birleşik Devletleri için ortalama 5 hektar olarak hesaplamışlardır. Türkiye için ise bu sayı kişi başına 2,7 hektar olarak hesaplanmaktadır. Ancak kentlerin ekolojik ayak izleri büyürken aynı zamanda fiziki olarak genişlemeye ve büyümeye de 
devam etmektedirler. Bu unsurlar göz önüne alındığında sürdürülebilir kentlere erişebilmek için atılan her adım, küresel ölçekte sürdürülebilirliğge katkı sağlayacaktır.

\section{Sürdürülebilir Kent Kavramı}

Sürdürülebilir kent kavramı için genel kabul görmüş tek bir tanımdan söz etmek mümkün değildir. Sürdürülebilir kent; ağırlıklı olarak kuşaklar arası eşitliğin garanti edilmesi için kaynakların kullanımı, doğal çevrenin korunması, yenilenemez kaynakların en düşük seviyede kullanımı, ekonomik güç, toplumsal özgüven, bireysel refah ve temel insani ihtiyaçların karşılanması gibi başlıklar altında incelenen bir kavramdır (Hardoy vd., 1992). Bileşenler açısından yaklaşıldığında sürdürülebilir bir kent; ekonomik, sosyal ve fiziki kalkınmanın bir arada yaşandığı kenttir (Soegijoko vd., 2001).

Sürdürülebilir kenti yalnızca üzerine kurulu olduğu coğrafi alanla sınılandırmak mümkün değildir. Sürdürülebilir bir kent kendisinden çok daha geniş bir coğrafya ile karşılıklı bağlantıları olan, çok boyutlu bir kavramdır (Camagni vd., 1998). Özetle sürdürülebilir kent; gelecek nesillerin ihtiyaçlarını karşılayabilecekleri bir çevrede ekonomik, çevresel ve sosyal sürdürülebilirliğin bir bütün olarak sağlandığı bir kavramdır.

\section{Sürdürülebilir Kent Kavramının Boyutlan}

Sürdürülebilir kent oluşturmanın amaçlarını özetleyecek olursak kent ile kentte yaşayan insanların uyumunun sağlanarak bireylerin yaşam kalitelerinin arttırılması; kentin kendi varlığını devam ettirmesi için altyapının oluşturulması ve son olarak da kentin doğa ile olan uyumunun sağlanması için gerekli koşulları yaratmak olarak özetlenebilir (Yazar, 2009; Altuntaş, 2012). Bu bağlamda sürdürülebilir kentlerin ekonomik, sosyal ve ekolojik olmak üzere üç boyutu bulunmaktadır.

Sürdürülebilir kentlerin ekonomik boyutu içinde kent içinde gelir dağılımı eşitliğinin sağlanması, istihdam alanlarının açılması, kentin altyapı sorunlarının çözülmesi, kentin sanayi yapısının kontrol edilmesi ve kentin rekabet gücünün arttırılması sayılabilir. Kent yönetimleri tarafından ekonomik boyut ile ilgili önlemler alınmadığı takdirde suç oranlarında artış gibi problemlerle karşlaşma ihtimalleri bulunmaktadır. Kişi başına olan suç oranlarının düşüklüğü, düşük işsizlik oranı ve adaletli gelir dağılımı ekonomik açıdan sürdürülebilir kent göstergesi olarak kullanılabilir. 
Sürdürülebilir kentlerin sosyal boyutunda yerel yönetimlerin kentte yaşayanların sosyal ihtiyaçlarını karşılaması hedeflenmektedir. Yoğun sosyal etkileşime elverişli kütüphane, sağlık merkezleri, toplum merkezleri ile bireyler arası ilişkinin güçlendirilmesine yönelik çalışmaların yapılması sosyal boyut altında sayılabilir. Sosyal boyut ile kişinin kente olan aidiyet duygusu güçlendirilmektedir. $\mathrm{Bu}$ amaçla yerel yönetimler tarafından toplum hizmetlerinde gençlerin rol alması, okullarda görev alan gönüllerin teşvik edilmesi gibi maliyetsiz sosyal sorumluluk projeleri üretilebilir.

Sürdürülebilir kentlerin en açık ve ölçülebilir özelliği ekolojik boyutudur. Yüksek yaşam kalitesi sağlamak amacıyla çevreye uyumlu ve doğaya saygilı yaşama alanlarının oluşturulması temel amaçtır. Kentlerin kıyaslanabilmesi için burada kullanılabilecek birçok gösterge bulunmaktadır. En temel gösterge hava kalitesi göstergesidir ve bunun için de yıl içinde Kükürt Dioksit (SO2) ve Partikül Madde (PM10) değerlerinin yasada belirtilen sınırları aştığı gün sayısina bakılır. Bunun yanı sıra imha edilen toplam katı atık hacmi de katı atık yönetimi göstergesi olarak kullanılabilir. Ayn zamanda kentlerde kullanılan araba sayısı (yakıt tüketimi), klima sayısı, bisiklet sayısı gibi değişkenlerle de küresel iklim değişikliğine olan etkileri ölçülebilmektedir.

Hava ve su kirliliği gibi problemler kentte yaşayan bireylerde ciddi sağllk problemlerine yol açmaktadır. Bunların en başında, düşük kilo ile doğan bebekler ve astım hastalığına sahip çocuklar gelmektedir. Kirliliğin nedenine bağlı olarak ciddi sağlık problemleri insanların yaşam kalitesi de düşmektedir. Bu yüzden de ciddi önlemler almak gerekmektedir. Sürdürülebilir kentlerin ekolojik boyutu sadece hava kalitesi ve atık yönetiminden oluşmamaktadır, aynı zamanda toplu taşıma ağları ve bisiklet ve yaya yolları ile çevreye uyumlu yaşam alanlarının yaratılması da demektir. Katı atıkların geri dönüşümü ve yenilebilir enerji kaynaklarının kullanımın arttırılması da gene bu boyut altındadir.

Temiz Hava Hakkı Platformunun (THHP, 2016a; 2016b) hazırladığı rapora göre Dünya Sağlık Örgütünün (DSÖ) hava kalitesi limitleri 81 ilin 41'inde aşımış durumda ve Türkiye'de Çankırı ili DSÖ́nün hava kalitesi şartlarını sağlayan tek il konumundadır. Şehirlerde yaşayan insanların yaşam kalitesinin arttırılması bağlamında özellikle ekolojik boyutu gerçekleştirmek için şehir yönetimlerine ciddi görevler düşmektedir. 


\section{Akıllı Kentler}

Doğal, yapay ve sosyal çevrenin üzerine göç, yatırımlar, küresel ısınma, kirlilik vb. ile çöken baskılarla baş etmede, artık pasif mekânsal bir birim olmanın ötesinde, konut, istihdam ve çevre kalitesi gibi politika alanları üzerinden aktif bir özne olarak kent işaret ediliyor. Önceki dönemlerde, sanayi imalatı, hane halkı tüketimi ve ulaşım gibi sektörel bir iz sürerek ilerleyen sürdürülebilirlik politikalarında bugün kent, doğal bir niş/mevki olarak belirmektedir (Camagni vd., 1998; Egger, 2006).

Bu kapsamda değerlendirilebilecek akıllı kent, bilgi ve iletişim teknolojiklerinin, altyapılar, mimari, gündelik nesneler ve bedenler ile birleşerek, sosyal, ekonomik ve çevresel sorunların çözümüne yönlendirildiği yer olarak tanımlanır (Townsend, 2013). Avrupa Birliği'nce Dijital Tek Pazar oluşturulması maksadiyla, Avrupa 2020 Stratejisi kapsaminda da telaffuz edilen ve de Avrupa Komisyonu'nunca 6 Mayıs 2015 tarihinde, üç temel başlıktan ve on altı farklı eylemden oluşan bir yol haritası sunulmuştur. Birlik, dijital ekonomi ve dijital toplum öngörüsünde akıllı kenti, geleneksel ağların ve hizmetlerin, bilgi ve iletişim teknolojileri yardımıyla vatandaşlar ve iş çevreleri için daha etkin hale getirildiği yer olarak tanımlamaktadır (EC-DSM, 2016). Akıllı kentin, ekonomik kalkınma, küresel rekabet, sosyal içerme ve çevresel sürdürülebilirliği geliştireceği; alıcılar, uyarıcılar, merkezileşmiş işlem kümelenmeleri ile fiziksel durumu gözlemleyerek bilgi toplayacağı ve bu sayede halkı ve yöneticileri uygun karar ve eylemlere yönlendireceği ifade edilmektedir (Datta, 2015; Fischer vd., 2012).

Akıllı kent, bilhassa iklim değişikliği ile ilişkilendirilerek düşünüldüğ̈̈̈nde, kaynak kullanımı ve düşük karbon salınımı duyarlılığının, kentsel ulaşım, binaların yalıtım ve aydınlatması gibi düzenlemelerle bütünleştiği bir kent olarak akla gelmektedir. Akıllı kent kavramında etkileşimli ve çözüm üreten bir kent yönetiminin tasvir edilmesinin yanı sıra güvenli kamusal alanlar ile yaşlanan nüfusun ihtiyaçlarının yanıt bulduğu bir mekân canlanmaktadır (EC-DSM, 2016; EC, EIP-SCC, 2016). Akıllı kentin, bilişim ve iletişim teknolojileri geliştiren şirketlerin (IBM, Microsoft vb.) ürün geliştirme aşamalarını kentler ile ilişkilendirerek genelleştirmeleri neticesinde kavramsallaştığı şeklindeki tanımlama ise sermayenin mekânı dönüştürücü gücünü bize gösterir (Batty vd., 2012).

Akıllı kentin tanımlayıcı özelliği, dijital aygıtlar ve sahip olduğu dijital altyapının ürettiği büyük verilerdir (Kitchin, 2014). Kent ile ilgili gerçek zamanlı veriyi mümkün kılan bu aygıtların, planlama ve harekete geçme aşamalarında daha etkin, sürdürülebilir, rekabetçi, açık ve şeffaf bir sürecin sağlayıcısı olacağı 
belirtilmektedir (Alazawi vd., 2011; Fischer vd., 2012; Alazawi vd., 2014). İlk aşamada akıllı kentin afetler ile mücadele ile ilişkilendirerek taşıdığı potansiyele, sonrasında ise muhtemel zayıflıklarına değinilecektir.

\section{Afetlerle Mücadelede Akıllı Kentler ve Bilgi ve İletişim Teknolojileri}

Nüfus sayımlarının, arşivlerin, harita etütlerinin vasıtasıyla yöneticilerin ve teknik adamların kentler ve sakinleri üzerine uzun yıllardır veriler topladıklarını ve biriktirdiklerini biliyoruz. Bunun yanı sıra, işletmelerin yaptıkları ticari işlemler, etkileşim içinde oldukları pazarlar ve müşterileri üzerinden oluşturdukları veri kayıtları da, alım satımın tarihi kadar eskidir (Kitchin, 2014). Ancak, bu veriler, kısa erimli, kesintili ve kısıtlı bir mekânsal alana ilişkin olmaları nedeniyle, güncel ve devingen gereklilikleri karşılamada yetersiz kalabilmekte, gerçek zamanlı, tüm mekânı kapsayan ve devamlı bir veri kaydı tutulmasının ihtiyacı belirmektedir. İhtiyacın, yüksek hacimli, süratli, zamansal ve mekânsal göndermeler içeren, ayrıntıll, kapsamlı ve bir kez kurulduktan sonra düşük maliyetli olması öngörülen bir sistem ile karşılanabileceği söylenmektedir (Kitchin, 2014). Verilerin akışı, bilgi ve iletişim teknolojilerinin, belli altyapıların ve süreçlerin gündelik hayata ve mekâna dâhil olması ile sağlanabilir. Bu kapsamda, veri toplamada kontrollü, otomatik ve gönüllü veri toplama usullerine başvurulur. Kentler için çoklu ağlardan, sürekli olarak otomatik biçimde toplanılan veriler anlamlıdır. Kentsel toplu taşımada kullanılan ve iz sürmeye imkân veren akıllı kartlar, otomatik plaka tanıma sistemleri ile taşıtların takibini sağlayan sistemler, elektrik, doğalgaz gibi hizmetlerin faturalarını ölçümleyen akıllı sayaçlar otomatik veri toplamaya örnek olarak verilebilir. Akıllı kent, kente yayılmış ve türlü biçimde iliştirilmiş pek çok alıcı ve uyarıcılar ile hem ışık, nem, sıcaklık, hava basıncı, su seviyeleri, sismik aktiviteler gibi çevresel süreçler hem de kentsel hareketlilik, hizmet tedarikleri gibi kentsel süreçlere ilişkin veri toplamayı hedeflemektedir. Bu sayede kent sakinleri, işletmeler ve yöneticiler -tam burada ve şu anda- olan bitene ilişkin toplanan veriler ile yönlendirilirken, yapılan tasnifleme ve değerlendirmeler kente ilişkin gelecek tasarilarının sağlam bir zemine oturtulmasını amaçlar (Fischer vd., 2012; Kitchin, 2014). Londra'nın ünlü kent gösterge panellerine benzer uygulamalar bugün ülkemizde de kimi belediyeler ve bakanlıklarca bilgilendirme maksadıyla kullanılmaktadır.

Akıllı kentlerin sahip olduğu bilgi ve iletişim teknolojileri altyapısıyla doğal afetler ve insan kaynaklı afetlerle karşı karşıya kalındığında, idare, itfaiye, sağlık kuruluşları, güvenlik güçleri, sivil savunma ekipleri, trafik müdürlükleri vb. 
ile vatandaş arasında hızlı, eşgüdümlü doğru bilgi akışını sağlamada üstünlüğe sahip olduğu vurgulanmaktadır. Akıllı kentlerde toplanan veriler gündelik olağan akışın rayından çıktığı afet anlarında erken uyarı ve tespit çabalarında hayati önem taşımaktadır. Kente ilişkin, gerçek zamanlı veri toplayan kablosuz sensor ağları, coğrafi bilgi sistemlerine dayanılarak oluşturulmuş, sensor ağlarının sağladığı veriyi yorumlamayı olanaklı kılacak olan bağlam ile karmaşık verilerin değerlendirilmesinde kullanılacak olan bir veri çözümleme çerçevelerinin varlı̆̆1 önemlidir (Fischer vd., 2012). Örneğin, bu sayede güç kaynaklarından akış kesilebilir, gaz basıncı düşürülebilir, santrallerin faaliyetleri durdurulabilir ve felaketin katlanmasınn önüne geçilebilir. 2011 yılında deprem ve tusunami ile sarsılan Japonya'da mobil operatörlerin ve teknoloji sağlayıcılarının planlama, acil durum ve iyileştirme safhalarında aktif bir rol aldığına değinilmektedir. Kentlerin bilgi toplama kabiliyetleri, veri analizi becerileri, akıllı/bilgisayar destekli ikaz sistemlerinin varlığ afetin etkisinin azaltılmasında ve afete maruz kalan bölgenin kısa sürede kontrol altına alınmasında etkili olmuştur. Trafik akışı, trenlerin seyri, havalimanlarına inişler, yeraltı trenin işleyişi, gaz istasyonları ve nükleer santraldeki faaliyet en kısa sürede afete ilişkin uyarılmış, cep telefonu kullanıcıları afetle ilgili bilgilendirilmiştir. Akıllı kentlerin, veri depolama ve paylaşmadaki kabiliyeti, bilgi ve iletişim teknolojileri altyapısıyla verileri etkin biçimde toplama, çözümleme ve yeniden ilgili birimlere dağıtmadaki başarısı, kentin afete karşı esnekliğinin ve hazırlığının tayin edici unsurudur. Tüm paydaşlar ile irtibatın sağlanması için mobil operatörlere yönelik gereken güçlendirmelerin yapılması ve operatörlerin diğer sensör ağlar ile ilişkilendirilerek, afet bölgesinde hava şartları, rüzgâr, radyasyon, su seviyesi vb. hakkında bilgi akışının sağlanmasında mobil operatörlerden faydalanılması istenilmektedir (GSMA, 2013).

Dikey ve yatay iletişimin gerekli şekilde sağlanmasının, zararın en aza indirilmesi ve kayıpların önlenmesinde önemi bilinmekle birlikte, iletişimin afet sonrası en temel zorluklardan biri olduğu kabul edilmektedir. Hızlı veri erişimi, zamanında ve güncellenen bilgilendirmelerin varlı̆̆ı, bilgilerin ölçümlenmesi ve bağlantı imkânlarının çeşitliliği, iletişimin sağlanabilmesi için önemlidir. Dikey iletişimde, durumun yukarıya doğru biçimde raporlanması, afet kumanda merkezlerince kararların verilmesinde ve değerlendirmeler neticesinde aşağı birimlere, yerinde talimatların verilmesi ise sahada atılacak adımların uygunluğunda tayin edicidir. Dikey ve yatay üniteler ile eş güdümlü bir ele alış için hem bilgi ve iletişim teknolojilerinin sağladığı hızlı bilgi akışı hem de çevrimdışı iletişim olanaklarının varlığı hassas bir meseledir. Bu bağlamda, doğal afetler ve insan kaynaklı afetlere hazırlık için önceleri simülasyon ve eğitimlere 
verilen ağırlı̆̆ın, son yıllarda siber güvenlik, uyarıcılar, lojistik, bilgi yönetimi gibi alanları da kapsar biçimde genişlediği gözlemlenmektedir (Meissner vd., 2002).

\section{Akıllı Kentlerin Toplumsal ve Ekonomik Boyutu}

Akıllı kentlerdeki işleyişte, teknoloji sağlayıcılarının, yazılım şirketlerinin, haberleşme operatörlerinin ve onlar arasındaki karşlıklı işbirliğinin belirleyici olduğu, bu bağlamda akıllı kentlerin bulut bilişim hizmetleri, veri analizi, mobil işletim, nesnelerin interneti vb. teknolojiler için yatırım ve iş fırsatları sunduğu ortadadır. Avrupa Komisyonu'nun Avrupa Bulut Girişimi'ni (European Cloud Initiative) başlatacağını duyurması, 2013 yılında dijital verilerin yüzde 20 'sınin bulutta depolandığı, 2020 yılına gelindiğinde bu oranın yüzde 40'a çıkarılmasının amaçlandığı düşünüldüğünde, akıllı kentin yazılım ve donanım şirketlerinin geliştirdikleri ürünler için uzun erimli pazar imkânı barındığı görülür (Akses, 2015). Akıllı kentin vaat ettiği girişimci kentleşme modeli, hizmet ve bilgi ekonomisini önceleyen, bilgi ve iletişim teknolojileri ve onlarm beslediği yan sektörlerdeki gelişim ile beşeri ve sosyal sermayeye yatırımların kentsel kalkınmayı sağladığı bir modeldir (Datta, 2015). Akıllı kentlerin, kentleşmeyle kalkınma ve modernliğin izinin sürüldüğü yirmi birinci yüzyıl reçetelerinden yalnız biri olduğu, bilgi ve iletişim teknolojilerinin ise bu yüzyılda, Mitchell'in ifade ettiği gibi tıpkı Antik Yunan Polis'inde agoranın merkeziliğine denk bir yeri olduğu notu düşülmelidir (Mitchell, 1995). Asya, Latin Amerika ülkelerinde ve ülkemizde "sanayileşmeyle kentleşme" ye bir alternatif gibi sunulan ve de bir "girişimci kentleşme" modeli olan akıllı kentlerde belli sektörlere yapılan yatırımlar ile kentsel kalkınmanın sağlanacağını öngörülmektedir.

\section{Türkiye'nin Akıllı Kentleri}

Türkiye'ye ilişkin olarak hazırlanan Akıllı Kentler Değerlendirme Raporu'nda, (2016), akıllı kentlerin oluşturulmasında finansman güçlüklerine değinilmektedir. Akıllı kent projelerinin, belediyeler düzeyinde, Akıllı Kent Otomasyonu Bilgi Sistemi (AKOS) kapsamında, e-devlet uygulamasına altyapı oluşturmak ve deprem risk haritaları hazırlanmak amacıyla uygulamaya konulduğu ve bu dönüşümler ile GSYİH'de yüzde 15 artss sağlandığı belirtilmiştir. Bu kapsamda, Yönetim Bilgi Sistemi (MIS), Coğrafi Bilgi Sistemi (GIS), Mobil Uygulamalar, Kent Sayısal Haritaları, Akıllı Sinyalizasyon, Akıllı Bina Mimarisi, Yenilenir Enerjiye ilişkin girişimler, Atık Yönetim Sistemi, E-Belediye, T-Belediye, 
Kiosk ve Mobil Belediye'nin faaliyete geçirilmesi sayılabilir (Akgül, 2013; Tarhan vd., 2013).

Ayrıca raporda, Türkiye'de büyükşehir belediyelerinin Akıllı Kent Endeksi ile hesaplanan dijital puanlarınn (dijital hizmetler, dijital operasyonlar ve dijital platformları içeren), işletmelerin dijital skorunun önüne geçtiğine değinilmiştir. Bu rapor bulguları neticesinde ülkemizde, kentleşmenin dijitalleşmeyi ivmelendirdiğini söylemek yanlış olmaz (Teknokulis, 2016; Akıllı Kentler, 2016). Castells' in (1989) akış mekânına geçiş biçiminde ifade ettiği, ağ toplumunun yükselişi ve küreselleşmeye ilişkin değerlendirmesinde, yatırımları ve kalifiye iş gücünü çekmek için kentlerin birbirleriyle rekabetin içine sokulduğu değerlendirmesiyle, akıllı kent yatırımlarını çekmek isteyen kentlerin dijitalleşme yarışına girebileceği öngörüsünde bulunulabilir. Türkiye Cumhuriyeti Kalkınma Bakanlığı'nca hazırlanan 2015-2018 yılı Bilgi Toplumu Stratejisinin Yenilenmesi Projesi ve Eylem Planında akıllı kentler, düşük karbonlu ekonomiye geçişte bir çözüm olarak telaffuz edilmiştir. Proje kapsamında, Bilgi Teknolojileri Sektörü, Genişbant Altyapısı ve Sektörel Rekabet, Nitelikli İnsan Kaynağı ve İstihdam, Toplumsal Dönüşüm, Bilgi Güvenliği, Kişisel Bilgilerin Korunması ve Güvenli İnternet, Bilgi ve İletişim Teknolojileri Destekli Yenilikçi Çözümler, İnternet Girişimciliği ve e-Ticaret ile Kamu Hizmetlerinde Kullanıcı Odaklılık ve Etkinlik gibi çalışma alanları tanımlanmıştır (Kalkınma Bakanlığı, 2015). Türkiye Bilişim Vakfı, Akıllı Kent Değerlendirme Raporu'na ilişkin sunuşunda İstanbul, Ankara, İzmir, Bursa, Adana, Antalya, Gaziantep ve Konya kentlerinin, on yll içinde üreteceği GSYİH'nin yüzde 17'sinin çeşitli doğal afet tehditleri sebebiyle risk altında olduğu ileri sürmüştür. Bu değerlendirme göz önünde tutulduğunda afetlerle mücadele ile bilgi ve iletişim teknolojilerine yapılan yatırımların ilişkiselliği ve yerindeliği kavranabilir (Akıllı Kentler, 2016).

Çevre ve Şehircilik Bakanlığı'nın 2020-2023 yılları için hazırladığı Akıllı Şehirler Stratejisi ve Eylem Planı ise veriye dayalı kendi kendini yöneten kentler için kapsamlı bir tasarım sunmaktadır. Çok ölçekli bir iş bölümü tasnifi ve dayanışma öngören ve ekosistem paydaşları olarak tarif edilen çok aktörlü bir süreç ile yürütülmesi amaçlanan Eylem Planının 15. Maddesi altında düzenlenen "Afet ve Acil Durum Yönetimi Bileşeninin Olgunluğunun Arttırılması" hedefinde sorumlu kuruluşlar olarak Afet ve Acil Durum Yönetimi Başkanlı̆̆ı, Çevre veŞehircilik Bakanlı̆ğ ve Yerel Yönetimler Genel Müdürlüğü yer almaktadır. Bu eylem kapsamında, akıllı kentlerin ihtiyaçları ve sunduğu çözümler uyarınca, afet ve acil durumlarda risk ve zararın azaltılması, planlamanın ve müdahalenin iyileştirilerek etkinliğin arttırlması, sivil savunma yönetiminin 
güçlendirilmesi, yerel düzeyde gerekli uyarlamaların yapılması ile tüm ölçeklerden aktörler arasında yönetişimin güçlendirilmesine dönük adımlara değinilmektedir. Eylem planının yüksek kritiklikte ve zor bir hedef olarak tanımladığı "Afet ve Acil Durum Yönetimi Bileşenin Arttırılması" hedefine, kentsel süreçlerin yaşamın her anını ve uzamı bütünüyle kuşattğı günümüzde akıllı kentler ekseninde altyapılar ve bilgi-iletişim sistemleriyle ilişkilendirilerek somutlaştırılarak erişilmesi amaçlanmaktadır (TC. Çevre ve Şehircilik Bakanlığı, 2019).

\section{Akıllı Kentlerin Eleştirisel Bir Okuması ve Değerlendirilmeler}

Akıllı kentin, eleştirel bir okuması, piyasa ve teknoloji tabanlı çözümler sunan bu kentsel, mekânsal projenin, Harvey (2001)'in mekânsal çözümler (spatial fix) olarak tarif ettiği, neoliberalizmin kriz döngüsünün mekânsal bir çözüm üretilerek aşıldığı ve de para-meta döngüsündeki tıkanıkların üstesinden mekânsal çözümler ile gelindiğine ilişkin değerlendirilmesi üzerinden yapılabilir. Diğer yandan bilgi ve iletişim teknolojileri üzerinden sağlanan verilerin bağımsız ve objektif olduğunun kabulü, yalnız verilerin, verileri anlamlandırmada teknik uzmanlıkların sinırlıklarını değil, verileri iletme, işleme, analiz etme süreçlerine dâhil olan kimselerin olası etkilerini de yok sayma manasına geldiğinden belli riskler taşır. Verileri düzenleyici ve denetleyici birimlerce tayin edilen erişim ve diğer işlemlere ilişkin sınırlandırmaların varlığı da bilgi ve iletişim teknolojileri üzerine kurulu bir düzene ilişkin kısıtlıkların olduğunu göstermektedir (Kitchin, 2014). Kentin bilgi sistemleri üzerinden yönetilmesini işaret eden akıllı kent, teknokratik bir kentsel yönetişimini işaretetmektedir. Bu anlamda müzakere kabiliyetinden yoksun kesimler pahasına, "teknokratik, yönetimsel ve girişimci" bir devletin, "vatandaş devleti" ne tercih edilmesi riskini taşımaktadır (Swyngedouw, 1996). Araçsal aklın ve de teknolojik çözümlerin kökleşmiş yapısal sorunların üstesinden gelinmesinde yetersiz kalacağı, farklı mekânların ve farklı toplulukların farklılaşan nitelikleri uyarınca sosyal, kültürel ve ekonomik alanda tamamlayıcı çabalarla desteklenmesinin gerekliliği not düşülmelidir (Datta, 2015). Diğer yandan, akıllı kentlerin işleyişinin bilgi ve iletişim teknolojileri ile iç içeliği, kentsel hizmetleri ve kentsel mekânı, virüs, sistem hataları, bilgisayarların çökmesi ve de bilgisayar korsanlarına karşı kırılganlaştırma riski taşımaktadır. Su, elektrik, demiryolu vb. kentsel altyapılara ilişkin siber saldırıların ihtimali, doğal afetlerle mücadelede de akıllı kentin sınırlılıklarını gösterir (Kitchin, 2014). Literatürde, akıllı kentlerde, güç ilişkilerinin dijital alana taşınıldığına değinilmektedir. Bu çerçevede, "dijital içerme" nin sağlanması, diğer bir ifadeyle kişi ve grupların dijital alana dâhil 
olması hususunda fırsat, erişim, bilgi ve kabiliyetlerin geliştirilmesi için önlemlerin alınıp, ilerleme kaydedilmesi çok büyük önem taşır. Aksi halde, akıllı kentte, kentsel planlama ve yönetimin siyasi elitler ile ayrıcalıklı sınıfların istek ve çıarlarına teslim edilmesi ihtimali belirir.

Ülkemizde, dijital içermenin ne oranda gerçekleştiğine ilişkin fikir yürütmeye olanak verebileceği gayesiyle kimi istatistiklere karşılaştırmalı olarak değinmek anlamlı olacaktır. Türkiye' de 2016 yılında, 43,2 milyon internet kullanıcısı bulunmaktadır, bu sayı nüfusun yüzde 55,9'una karşılık gelirlerken (Internet Live Stats, 2016) bu sayı Ocak 2020 yllında 62,07 milyona ulaşmıştır, bu sayı nüfusun \%74'üdür (Kemp, 2020). Dünya Bankası verileri ise 2014 yılında her 100 kişiden 51'nin son on iki ayda internete erişimi olduğunu göstermektedir. 2018 yılında ise nüfus içerisinde internet kullanıcılarının oranı \%71'dir. Veriler ancak karşılaştırmalı biçimde incelendiğinde anlam ifade edeceğinden 2018 yılında, her 100 kişiden Danimarka'da 97'sinin, Birleşik Krallıkta 95'inin, Brezilya'da 70'inin, Afganistan'da ise 14'ünün internete erişimi olduğu göz önünde bulundurularak değerlendirilmelidir (The World Bank, 2019). Bu anlamda, dijital içermenin geliştirilmesi çabaları akıllı kent kapsamında kent hakkının bir görünümü olarak düşünmek yanlış olmayacaktır. 2015 yılında, Hindistan Dholera akıllı kent projesi üzerinden yapılan bir inceleme, dijital içermenin sağlanmamıss olduğu bir denklemde, dijital teknolojilerin bilginin, gücün ve gelirin dağllışındaki belirleyiciliğinin sosyal adaleti tesis etmedeki yetersizliğine değinilmiştir (Datta, 2015). Akıllı kent ile erişilmesi hedeflenen sosyal ölçütlerin ve katılımın sağlanılamadığı bir durum, akıllı kent idealinin ekonomik alanla sınırlı bir görünümü haline gelir. Bunun yanı sıra, akıllı kentlerde, bireylerin ve toplulukların eylemlerinin ve işlemlerinin izleniyor ve kaydediliyor olmasl, gözetim toplumunun özgürlükler aleyhine yükseliyor olmasına dikkat çekilerek eleştirilmektedir (Kitchin, 2014). Son olarak, akıllı kentlerdeki katılım ve birlikte karar almanın sağlanabilmesi için dijital vatandaşlık üzerindeki vurgunun, ancak sosyal, politik, coğrafi ve ekonomik anlamda dışlanmış vatandaşların kent işleyişini sorgulayarak şekillendirebildiği bir ortamda gerçekleşebileceği hatırlanmalıdır.

\section{Afetlerin, Sürdürülebilir Kentler Ve Akıllı Kentler Açısından Değerlendirilmesi}

Sürdürülebilir kentler kavramı daha çok şehirde yaşayanların yaşam kalitesini arttırmaya yönelik olduğundan dolayı doğal afetler öncesinde ve afetlere hazırlıklı olmak anlamında önem kazanırken; akıllı kentler doğal afet sonrasında acil müdahale gerektiği durumlarda özellikle zorunlu hale gelmektedir. Doğal 
Afetlerin yüzde 61'i depremlerden kaynaklanmaktadır. Türkiye'deki 81 ilin $55^{\prime} \mathrm{i}$ birinci derecede deprem bölgesindedir. Nüfusun yüzde 98'i deprem aç1sından riskli bölgede yaşamaktadır. Türkiye yaşadığı en büyük doğal afet felaket resmi rakamlara göre 32.962 kişinin hayatını kaybettiği 1939 Erzincan depremidir (TMMOB, 2012)

\section{Marmara (Gölcük-Kocaeli) Depremi}

7,8 şiddetinde 17 Ağustos 1999 da merkez üssü Gölcük olan depremde 17.408 kişinin hayatını kaybetmesinin yanında 43.953 kişi de yaralandı. 327.871'i konut, 48.508 'i işyeri ve bunların da 112.724 'i yıkık ve ağır hasarlı bina olmak üzere toplamda 376.479 konut ve işyerinde hasar tespit edilmiştir. Toplamda 16 milyon insanın farklı düzeylerde etkilendiği düşünülmektedir (TMMOB, 2012).

Marmara Depremi özellikle Gölcük'ün bağlı olduğu Kocaeli başta olmak üzere, Sakarya, Yalova, Bolu ve Düzce illerini ciddi düzeyde; İstanbul, Bursa ve Eskişehir illerini ise ikincil düzeyde etkilemiştir. Bu yedi şehrin nüfus içindeki payı yüzde 23 iken GSYİH içindeki payı da yüzde 35'dir. Türkiye'deki üretimin üçte biri, sanayi üretiminin yarısı ve ihracatın yarısından fazlası da bu bölgeden yapılmaktadır. Ciddi şekilde etkilenen dört şehrin nüfus içindeki payı yüzde 4 olmasına rağmen GSYİH içindeki payı nüfusun iki katına yakın yani yüzde 7'nin üzerindedir.

Tablo1. Marmara Depreminin Makroekonomik Maliyetleri (Milyar Amerikan Doları)

\begin{tabular}{|c|c|c|c|c|}
\hline & TÜSİAD & $\begin{array}{l}\text { Şehir } \\
\text { Odası }\end{array}$ & Planciları & Dünya Bankası \\
\hline DOĞRUDAN MALIYYETLER & 10 & $6,6-10,6$ & & $3,1-6,5$ \\
\hline Mesken & 4 & $3,5-5$ & & $1,1-3$ \\
\hline Şirket & 4,5 & $2,5-4,5$ & & $1,1-2,6$ \\
\hline Altyap1 & 1,5 & $0,5-1$ & & 0,9 \\
\hline DOLAYLI MALIYETLER & 2,8 & $2-2,5$ & & $1,8-2,6$ \\
\hline Katma-Değer Kaybı & 2 & $2-2,5$ & & $1,2-2$ \\
\hline Acil Yardım Harcamaları & 0,8 & - & & 0,6 \\
\hline Toplam Zarar Maliyetleri & 13 & $9-13$ & & $5-9$ \\
\hline \multicolumn{5}{|l|}{ İIINCIL ETKILER } \\
\hline Cari Açık Kayıpları & 2 & - & & 3 \\
\hline Mali Kayıplar & 2 & 5,9 & & $3,6-4,6$ \\
\hline İş kayıpları (bölgedeki işgücünün \%) & - & - & & $\% 20-50$ \\
\hline
\end{tabular}

(Bibbee vd., 2000) 
Marmara Depreminin ekonomik, sosyal ve ekolojik boyutlarını inceleyecek olursak "Sürdürülebilir Kentler" kavramının önemi ortaya çıkacaktır. Bir kentin sürdürülebilirliğinin sağlanmasında yerel yönetimlere ciddi görevler düşmektedir. Bir şehrin sürdürülebilirliği arttırıldığı takdirde doğal afetlere savunmasız yakalanma olasılığı azalacaktır.

Dünya Bankasının 1999 Türk (Marmara) Depremlerinin Ekonomik Etkilerini araştırdığı rapor; ekonomik altyapıda ortaya çıkan hasar, üretime (girişimcilere) olan etkisi, finansal sisteme olan yükü ve doğal afetin toplam ekonomik maliyetleri alt başlıkları altında yaşanan doğal afetin ekonomik etkilerini incelemiştir (Bibbee vd., 2000).

Deprem sonrasında enerji, ulaşım ve haberleşme alanında neredeyse bütün altyapı zarar görmüştür. Elektrik, su, kanalizasyon hatlarının yenilenmesi yani altyapı maliyetleri gibi doğrudan maliyetlerin yanı sıra dolaylı maliyetler ve ikincil etki diye adlandıracağımız maliyetler de söz konusudur. Depremin makroekonomik maliyetleri Tablo 1'den detaylı bir şekilde görülebilir. TÜSİAD'ın tahminine göre depremin Türkiye ekonomisine toplam maliyeti 30 milyar dolardır.

Marmara depreminin sosyal boyutunun en temel göstergesi özellikle Gölcük'te yaşayan beş kişiden biri yaşamını kaybetmiştir. Evleri ve işyerleri yıkılan insanlar için geçici barınaklar oluşturulmuş. Yüzde 20-50 arasında işgücünün işini kaybettiği de hesaba katılacak olursa diğer illere göç etmek zorunda kalmışlardır. 43 okul tamamen yıkılmış, 377 tanesi de ciddi anlamda hasar almıştır. Yaklaşık 25 bin öğrencinin başka okullara transferi gerçekleşmiştir. Bunun da ekonomik olarak maliyeti 1999-2000 öğretim yılı için yaklaşık 100 milyon dolar olarak hesaplanmıştır. 28 sağlık merkezi ve 10 hastane ciddi hasar almıştır. Sağlık altyapısının da maliyeti 40 milyon dolar olarak hesaplanmıştır. Afet ve acil durumlar için belirlenme alanlarının yeterliliğini İzmit için inceleyen Gerdan ve Şen (2019) bu alanların erişilebilirlik açısından yetersiz olduğunu belirtmiştir.

Marmara depreminin ekolojik boyutuna bakılacak olursa en temel sorunun yerleşim yerinin fay hattı üzerine kurulması ve büyük ölçekli şehirleşmenin gevşek zemin üzerinde oluşmasına izin verilmesi olduğu açıktır. Bir de bunlara yetersiz inşaat malzemesi kullanımı eklendiğinde depremin etkisi yıkıcı olmuştur. 1995 yılında Japonya' da yaşanan aynı büyüklükteki depremde hiçbir can kaybının olmaması da olayın vahametini arttırmaktadır.

Akıllı Kentler kavramı açısında 1999 yılında cep telefonu ve internet kullanımının günümüze göre kısıtlı olmasının yanında deprem sonrasında bölge de 
elektrikler kesilmesiyle birlikte cep ve telefonlarda devre dışı kalmıştır. Bu da özellikle ilk müdahale ve ilk yardım aşamasında ciddi sorunlara yol açmıştır.

\section{Sonuç}

Türkiye nüfusunun yüzde 98'i deprem bölgelerinde yaşamaktadır. Türkiye'de en büyügü 1939 ve 1999 depremleri olmak üzere bir yıl için de yaklaşık bin adet küçüklü büyüklü deprem gerçekleşmektedir. En son 2011 yllında yaşanan Erciş-Van merkezli depremde 604 kişi hayatını kaybetmiş̧ir. Bunların yanı sıra Karadeniz Bölgesinde doğaya aykırı yani nehir yataklarına yapılan çarpık yapılaşma sonucunda ortaya çıkan sel felaketleri de mevcuttur.

Kentlerin doğal ve yapılı çevresinin mahiyetinin ve kent sakinlerinin hazırlığı, doğal afetlerin yıkım seviyesinde belirleyicidir. Afetlerle mücadelede doğal, yapılı çevre ve kent sakinleri üzerine dönüştürücü idealleri ile sürdürülebilir ve akıllı kentlerin anlamlı bir çerçeve sunmaktadır. Sürdürülebilir Kentler, doğayla uyumlu, kentte yaşayanların hayat standartlarını arttırmayı amaçlayan ve çevreye saygılı kent oluşturmakla ilgidir. Bu özellikleri sağlayan kentler de doğal olarak doğal afetlere karşı daha duyarlıdır. Akıllı Kentler ise kentin idari yapısında görevli personelle (itfaiye, hastane, güvenlik güçleri) kentte yaşayanlar arasında bilgi ağının kurulması ve bilgi iletişim teknolojilerinin kullanımı ile ilgili olduğundan afet sonrasında müdahalenin çabuk ve hızlı gerçekleştirilebilmesini sağlamaktadır.

Sürdürülebilir Kentler, şehri "gelecek kuşaklar"a ve olası afetlere karşı hazırlamakta iken Akıllı Kentler ise bilgi iletişim ve bilişim teknolojileri ile afete hazır bir planlama ve politika izlemenin, bilgi iletişim ve bilişimin araçlarının bu süreçlere aktif biçimde dâhil edilmesi ile olanaklı olabilecektir. Bu tek başına yeterli değildir ama gerekli bir koşuldur. 


\title{
Extended Abstract
}

\section{The Sustainable and Smart Cities: Marmara Earthquake \\ *}

Dilek Çetin

Yağmur Kara

ORCID: 0000-0001-5377-5561
Zeynep Ceren

Henriques Correia

ORCID: 0000-0002-1080-4905

ORCID: 0000-0002-0854-8746

\begin{abstract}
- ORCID: 0000-0001-537/-551
\end{abstract}
Sustainable development sets foundation of social, economic and environmental policies countries across world. In $2018,55.3 \%$ of the world population lives in cities and this ratio is expected to exceed $75 \%$ in 2030. In this context, the growth of cities should be monitored and regulated. The cities, without a forward looking city policy, are in desperate straits towards to disasters. While ensuring that city is harmonized with the nature, enhancing life quality should also be pursued. The policies of sustainable city aim to ensure harmony between the men and the nature, by doing so preparing the city to disasters. Whereas smart city policies have potential to contribute cities' recovery by means of information and communication technologies. Thus, the cities would not be desperate against the disasters.

"Sustainability" concept emerges in the aftermath of the Second World War with the debates on whether world will continue to be a habitable place or not (Kidd, 1992). Club of Rome was assembled in 1968 with its emphasis on physical growth has its limits and published their report on "Limits to Growth" in 1972. In this report, it is exerted that solely focusing on the economic growth is causing destruction on the ecology (Meadows, 1972). Moreover, denial of dependency among socio-economic development and nature cannot be maintained.

Sustainable cities emerge as keystone to sustainable development and the cities lacking forward looking city policy are more susceptible to disasters. Although it is hard to define sustainable cities, there is consensus that it can be analyzed through the terms of equality of resource usage between the generations, protection of natural environment, low usage of non-renewable resources, distribution of economic power, social self-confidence, individual welfare and basic human necessities (Hardoy et al., 1992). Sustainable city, in 
sum, is city where economic, social and physical development is seen together in harmony (Soegijoko et al., 2001).

The core purpose of forming a sustainable city is to harmonize the city and its denizens, to increase the quality life of individuals and to maintain an environment that ensures the rapport of the city with its nature (Yazar, 2009; Altuntaş, 2012). In this regard, three dimensions, economic, social and ecological, are equally set at the core of sustainable cities. The economic dimension of sustainable cities involves assuring just distribution of wealth, generating new employment areas, solving issues of infrastructural accessibility, monitoring city's industrial structure while ensuring its competitiveness. Thus, low rates of criminal records, low unemployment rate and fair income equality are used as an indicator of sustainable city from an economic perspective. Sustainable cities' social dimension is also multi-layered, it covers the local governments' responsiveness the social needs of people living in the city through means of facilities as libraries, health centers, community centers for strengthening interactions among denizens.

Sustainable city's ecological component stands for ensuring environmentally friendly living spaces and spreading environmental consciousness to generate higher life quality for all components of its nature, including its human denizens. In the literature, quality of the air has counted among primary indicators and for that account, exceedance of Sulphur dioxide (SO2) and particulate pollution (PM10) are set significant to be monitored for the days in a year. Besides global climate change impacts are defining for sustainable city policies with numerous wide-range indicators as number of cars (consumption of fuel), the number of air conditioning, the number of bicycles etc. In relation to disaster management, sustainable city policies are defining mostly in advance to time when actual disasters occur. Sustainable cities contribute to disaster preparedness by caring and improving social, economic, and ecological components of the city.

On the other hand, smart cities are emerged as a recent phenomenon that include usage of information and communication technologies, infrastructures in interaction with daily objects to overcome social, economic, and environmental issues at stake (Townsend, 2013). In this regard, European Union sets a road map with three main headlines and sixteen different actions in Europe 2020 Strategy to form a Digital Single Market (EC-DSM, 2016). Smart cities appear as new endeavor to ensure economic development, global competitiveness, social inclusion, and environmental sustainability (Datta, 2015; 
Fischer et al., 2012). Smart cities aspires to achieve resource consumption sensitivity with its low carbon policies to contribute climate change mitigation. Inclusion of digital instruments and infrastructure with big data appears as core of smart city policies (Kitchin, 2014).

In times of natural or human-made disasters, smart cities have potential to coordinate fire service, health institutions, security forces, civil service organizations, traffic directorate etc. by means of their information and communication technology infrastructures. As disasters would be detected timely by gathering the real-time data, it would provide an advantage for taking necessary measures (Fischer et al., 2012). Thus, actions such as power flow cut, curtailing gas pressures, halting operation of power plants would tremendously contribute to eliminate or to reduce disasters' destructive effects. Smart city policies have been becoming particularly mandatory in case emergency response is required in the aftermath of a natural disaster.

Its known that 61 percent of natural disasters are caused by earthquakes, whereas 55 of the 81 provinces in Turkey is in the first-degree earthquake area and 98 percent of the population lives in an earthquake-risky area. On $17^{\text {th }}$ of August 1999, Marmara earthquake hit as Gölcük its epicenter with 7.8-magnitude. Its recorded that 17,408 people lost their lives, and 43,953 people were injured. A total of 376,479 houses and workplaces were damaged, including 327,871 residences, 48,508 workplaces and 112,724 destroyed or severely damaged buildings. A total of 16 million people is thought to be imposed to earthquake on various levels. (TMMOB, 2012). According to TUSİAD, total cost of earthquake is approximately 30 billion Dollars.

Against this background, cities emerge as a niche in disaster mitigation and management alongside a national or sectoral disaster management policies. In Turkey, Marmara earthquake with its record of highest loss from a disaster needs to be revisited with reconsidering in line with sustainable and smart city policies. This study asserts that governments should transform from fatalistic, curative, reactive to self-confident, protective, and pro-active. It's clear that adapting sustainable and smart city policies have potential to contribute both city and national level disaster management and mitigation strategies.

\section{Kaynakça/References}

Akgül, M.K. (2013) 'Kentlerin e-dönüşümü, akıllı kentler', 15 Mart 2016 tarihinde https://anahtar.sanayi.gov.tr/tr/news/kentlerin-e-donusumu-akilli-kentler/416 adresinden erişilmiştir. 
Akıllı Kentler (7 Mart 2016) Akıllı kentler değerlendirme raporu. 15.03.2016 tarihinde http://www.akillikentler.org/akilli-kentler/2051/6/akilli-kentler-degerlendirme-raporu.html. adresinden erişilmiştir.

Akses, S. (2015) AB'de dijital tek pazarm oluşturulmasına doğru, iktisadi kalkmma vakfi değgerlendirme notu. No:133, İstanbul, İktisadi Kalkınma Vakfı

Alazawi, Z., Alani, O., Abdljabar, M.B., Altowaijri, S. ve Mehmood, R. (2014) A smart disaster management system for future cities. Proceedings of the International Workshop on Wireless and Mobile Technologies for Smart Cities, Philadelphia, ABD, 11- 14 Ağustos.

Alazawi, Z., Altowaijri, S., Mehmood, R. ve Abdljabar, M.B. (2011) Intelligent disaster management system based on cloud-enabled vehicular networks. ITS Telecommunications (ITST), 11th International Conference, St. Petersburg, Russia, 23-25 Ağustos.

Altuntaş, A. (2012) Sürdürülebilir toplumlar ve metropollerin baskılarında kurtulmak için alternatif bir yol: Sürdürülebilir kentler, Mustafa Kemal Üniversitesi Sosyal Bilimler Enstitüsü Dergisi, 9(17), 135-148.

Batty, M., Axhausen, K.W., Giannotti, F., Pozdnoukhov, A., Bazzani, A., Wachowicz, M. ve Portugali, Y. (2012) Smart cities of the future. UCL Working Papers Series No:188, London, University College London, Center for Advanced Spatial Analysis.

Bell, S. ve Morse, S. (2008) Sustainability indicators, measuring the immeasurable?. Earthscan: London

Bibbee, A., Gönenç, R., Jacobs, s., Konvitz, J. ve Price, R. (2000). Economic effects of the 1999 Turkish Earthquakes: An interim report. OECD Economics Department Working Papers, No. 247, OECD Publishing, Paris, https://doi.org/10.1787/233456804045.

Brown, L. (1981) Building a sustainable society. New York, Norton.

Bugliarello G. (2006) Urban sustainability: Dilemmas, challenges and paradigms. Technology in Society, 28, 19-26.

Camagni, R., Capello, R. ve Nijkamp, P. (1998) Towards sustainable city policy: An economy-environment technology Nexus. Ecological Economics, 24(1), 103-118.

Castells, M. (1989). The informational city: Information technology, economic restructuring, and the urban-regional process. Oxford: Basil Blackwell Press.

Clark, W.C. ve Dickson, N.M. (2003) Sustainability science: The emerging research program. Proceedings of the National Academy of Science, 100(14), 8059-8061.

Datta, A. (2015) New urban utopias of postcolonial India. Entrepreneurial urbanization'in Dholera smart city. Gujarat', Dialogues in Human Geography, 5(1), 3-22.

Egger, S. (2006) Determining a sustainable city model. Environmental Modelling \& Software, 21 (9), 1235-1246.

European Commission, Digital Single Market (DSM) (2016) Smart cities. 15.03.2016 tarihinde https://ec.europa.eu/digital-single-market/smart-cities adresinden erişilmiştir.

European Commission, Smart Cities and Communities (EIP-SCC) (2016) The European Innovation Partnership on Smart Cities and Communities. 15.03.2016 tarihinde http://ec.europa.eu/eip/smartcities/ E adresinden erişilmiştir. 
Fischer, J., Redlich, J.P. ,Scheuermann, B., Schiller, J., Günes, M., Nagel, K. ve Sombrutzki, R. (2012) From earthquake detection to traffic surveillance about information and communication infrastructures for smart cities. In Haugen Ø., Reed R., Gotzhein R.(ed.) System Analysis and Modeling: Theory and Practice içinde (s.121-141).Berlin Heidelberg, Springer Press,

Gerdan, S. ve Şen, A. (2019). Afet ve acil durumlar için belirlenmiş toplanma alanlarının yeterliklerinin değerlendirilmesi: İzmit örneği, İdealkent, 28 (10), 962-983.

GFN, Küresel Ayak İzi Ağı (2015). Global Footprint Network, World Footprint. 15.02.2016 tarihinde http://www.footprintnetwork.org/en/index.php/GFN/page/world_footprint/ adresinden erişilmiştir.

GSMA (2013) Smart cities, smart city resilience learning from emergency response and coordination in Japan. 15.03.2016 tarihinde http:/www.gsma.com/connectedliving/smart-city-resilience-learning-from-emergency-response-and-coordination-injapan/ adresinden erişilmiştir.

Hardoy, J.E., Mitlin, D. ve Satterthwaite, D. (1992). Environmental problems in third world cities, London, Earthscan.

Harvey, D. (2001) Globalization and the "Spatial Fix". Geographische Revue, 2001/2, 23-30.

Handl, G. (2020) Introductory Note - Declaration of the United Nations Conference on the Human Environment. 15.08.2020 tarihinde https://legal.un.org/avl/ha/dunche/dunche.html adresinden erişilmiştir.

Holden, M., Roselan, M., Ferguson, K., ve Perl, A. (2008) Seeking urban sustainability on the world stage, Habitat International, 32, 305-317.

Internet Live Stats (2016) Turkey Internet Users. 01.05.2020 tarihinde http://www.internetlivestats.com/internet-users/turkey/. adresinden erişilmiştir.

Kalkınma Bakanlığı (2015) 2015-2018 Bilgi Toplumu Stratejisi ve Eylem Planı. Bilgi Toplumu Dairesi Başkanlığı, Ankara

Kates, R., Clark W. ve Corell, R. (2001) Sustainability science. Science, 292 (5517), 641-642.

Kates, R.W., Parris, T.M. ve Leiserowitz, A.A. (2005). What is sustainable development? Goals, indicators, values, and practice. Environment: Science and Policy for Sustainable Development, 47(3), 8-21.

Kemp, S. (2020). Digital 2020: Turkey. 15.08.2020 tarihinde https://datareportal.com/reports/digital-2020-turkey adresinden erişilmiştir.

Kidd, C.V. (1992) The evolution of sustainability. Journal of Agricultural and Environmental Ethics, 5(1), 1-26.

Kitchin, R. (2014) The real-time city? Big data and smart urbanism. GeoJournal, 79(1), 1-14.

Meadows, D.H., Meadows, D.L., Randers, J. ve Behrens, W. W. (1972) The limits to growth, Universe Books.

Meissner, A., Luckenbach, T., Risse, T., Kirste, T. Ve Kirchner, H. (2002). Design challenges for an integrated disaster management communication and information system. The First IEEE Workshop on Disaster Recovery Networks, New York, ABD.

Mitchell, W.J. (1995). City of bits. Space, place. Cambridge, MA, MIT Press. 
Rees, W.E. (1992) Ecological footprints and appropriated carrying capacity: What urban economics leaves out. Environment and Urbanization, 4(2), 121-130.

Soegijoko, B., Tjahjati, S., ve Kusbiantoro, B.S. (2001) Globalization and the sustainability of Jabotabek, Indonesia. Lo, F. ve Marcotullio, P. J. (ed.) Globalization and the Sustainability of Cities in Asia Pacific Region, United Nations Press.

Swyngedouw, E. (1996) 'Reconstructing citizenship, the re-scaling of the state and the new authoritarianism: Closing the Belgian Mines'. Urban Studies, 33(8), 1499-1521.

Tanguay, G.A., Rajaonson, J., Lefebvre, J.F. ve Lanoie, P. (2010) Measuring the sustainability of cities: An analysis of the use of local indicators. Ecological Indicators, 10, 407-418.

Tarhan, C., Coşkun, Z. ve Zülfikar, C. (2013) Deprem bilgi sistemi. 2. Türkiye Deprem Mühendisliği ve Sismoloji Konferansı, MKÜ, Hatay, Türkiye, 25-27 Eylül.

T.C. Çevre ve Şehircilik Bakanlığı, (2019). 2020-2023 Ulusal Akıllı Şehirler Stratejisi ve Eylem Plam (2019). 5.05.2020 tarihinde https://www.akillisehirler.gov.tr/wp-content/uploads/EylemPlani.pdf, adresinden erişilmiştir.

Teknokulis (1 Mart 2016) Türkiye akıllı kent değerlendirme raporu yayınlandı. 15.03.2016 tarihinde http://www.teknokulis.com/haberler/guncel/2016/03/01/turkiye-akilli-sehirlerdegerlendirme-raporu-yayinlandi. adresinden erişilmiştir.

Temiz Hava Hakkı Platformu (THHP), (2016a) Türkiye hava kirliği raporu:İllere göre PM10 Analizi. 20.02.2016 tarihinde http:/temizhavaplatformu.org/wp-content/uploads/2016/03/I\%CC\%87LLERE-GO\%CC\%88RE-PM10-ANALI\%CC\%87ZI\%CC\%872015-.pdf. Adresinden erişilmiştir.

Temiz Hava Hakkı Platformu (THHP) (2016b) Türkiye hava kirliği raporu: İllere göre SO2 Analizi. 20.02.2016 tarihinde http://temizhavaplatformu.org/wp-content/uploads/2016/03/I\%CC\%87LLERE-GO\%CC\%88RE-SO2-ANALI\%CC\%87ZI\%CC\%872015.pdf adresinden erişilmiştir.

The World Bank (2019) Internet users. 01.05.2020 tarihinde http://data.worldbank.org/indicator/IT.NET.USER.P2 adresinden erişilmiştir.

TMMOB Makine Mühendisleri Odası (2012). Türkiye'de deprem gerçeği ve TMMOB Makine Mühendisleri Odasinnn Önerileri. Yayın No: MM0/587. 25.03.2016 tarihinde http://www.mmo.org.tr/resimler/dosya ekler/667cd09b1e1820f ek.pdf?tipi=3\&turu=X\&sube=0 adresinden erişilmiştir.

Townsend, A.M. (2013) Smart cities: Big data, civic hackers, and the quest for a new utopia, New York/ London, WW Norton \& Company.

Türkiye Bilişim Vakfı (2016) Şehrin akull hali. 15.03.2016 tarihinde http://www.tbv.org.tr/sehrin-akilli-hali,DP-1094.html. Adresinden erişilmiştir.

UN (2018). World urbanization prospects 2018, department of economic and social affairs: population dynamics. 15.03.2020 tarihinde esa.un.org/unpd/wup/DataQuery/ adresinden erişilmiştir.

Wackernagel, M. (1994) Ecological footprint and appropriated carrying capacity: a tool for planning toward sustainability. Doktora Tezi. Vancouver, Canada: School of Community and Regional Planning, The University of British Columbia, OCLC 41839429. 
Wackernagel, M. ve Rees, W.E. (1996) Our ecological footprint: Reducing human impact on the earth, New Society Publishers.

WCED (1987) World commision on environment and development. Our common future. Oxford, Oxford University Press.

WWF (2012) Dünya Doğayı Koruma Vakfi Türkiye'nin ekolojik ayak izi raporu. 07.02.2015 tarihinde http://www.footprintnetwork.org/images/article_uploads/Turkey_Ecological_Footprint_Report_Turkish.pdf. adresinden erişilmiştir.

Yazar, K.H. (2009). Sürdürülebilir kent: Göstergeleri, formu ve planlama süreci. 21. Uluslararası Yapı ve Yaşam Kongresi (20-21 Mart 2009) Bildiriler Kitabı, (Ed: Nilüfer Taş ve Murat Taş), Bursa: TMMOB Mimarlar Odası Bursa Şubesi. 